УДК 004:[378.147.091.33-027.22:811.161.2]

Решетняк Олена Олександрівна

кандидат філологічних наук, доцент кафедри української мови та літератури

ДВНЗ «Донбаський державний педагогічний університет», м. Слов'янськ, Україна

0000-0002-8039-3929

reshetnyak.alena.@ukr.net

\title{
ЗАСТОСУВАННЯ ІНТЕРНЕТ-ОРІЕНТОВАНОЇ ПРОЕКТНОЇ ТЕХНОЛОГІЇ НАВЧАННЯ СУЧАСНОЇ УКРАЇНСЬКОЇ ЛІТЕРАТУРНОЇ МОВИ В ЗАКЛАДАХ ВИЩОЇ ОСВІТИ
}

\begin{abstract}
Анотація. У статті розглянуто особливості впровадження проектної технології у вивчення навчальної дисципліни «Сучасна українська мова» на філологічному факультеті у ВНЗ. Як спосіб і засіб вивчення й аналізу науково-методичної літератури визначено сутність основних ознак методу проектів, його види й етапи, окреслено методику реалізації проектної діяльності під час вивчення філологічних дисциплін. Для реалізації проектного дослідження рекомендовано використовувати інформаційно-комунікаційні технології, що допомагають оптимізувати навчальний процес, зробити його цікавим i творчим. Актуальність роботи зумовлена потребою впровадження в навчальний процес нових ефективних педагогічних технологій, інтерактивних методів і прийомів навчання, що допомагають розвивати пізнавальні здібності студентства, формувати вміння знаходити шляхи розв'язання певних проблем завдяки залученню різноманітних форм діяльності.
\end{abstract}

Ключові слова: мова; компетентність; проектні технології (метод проекту); самостійна робота; інноваційні форми роботи; інтерактивні вправи; інтернет-ресурси.

\section{1. ВСТУП}

Постановка проблеми. Сьогодення вимагає від викладача ВНЗ пошуку нових форм і методів навчання, упровадження яких у педагогічну практику сприяє активізації навчально-пізнавальної діяльності студентів, підвищувало ефективність набуття нових знань, розвивало креативність, навички групової, індивідуальної та колективної роботи. Однією 3 альтернатив навчальної системи $\epsilon$ метод проектів, що $\epsilon$ сукупністю послідовно-пошукових, проблемних методів, творчих за своєю сутністю.

Проблема реалізації проектних технологій під час вивчення курсу «Сучасної української літературної мови» (далі - СУЛМ) наразі є актуальною, бо передбачає використання різноманітних методів і прийомів навчання, інтегрування знань й умінь 3 різних галузей науки, техніки, технології, творчих галузей. Сучасний студент представник так званого «медійного покоління», тому переважну кількість часу він проводить в соціальних мережах. Для нього, на думку О. Ісаєвої, «зазвичай, характерні дві крайнощі: гіперактивність чи пасивність, пригніченість і навіть байдужість. Йому, як і всім нам, нині не вистачає часу. Прагнучи все встигнути, підключаючи всі канали сприйняття інформації, врешті-решт людина зараз знає багато чого, але поверхово, почасти не здатна до самостійного аналізу і нерідко втрачає бажання пізнавати щось нове. Така розірваність сприйняття впливає на формування «мозаїчного» мислення» [1]. Тому перед викладачем постає важливе завдання: скористатися індивідуальними уподобаннями студентів, створити адекватне середовище, що забезпечувало б можливість вільного доступу до різних джерел інформації, спілкування з однолітками, колективної роботи та прийняття рішень. А це вочевидь підвищить рівень мотивації студентів до пошуково-дослідницької роботи. Цьому сприяє метод проектів, який використовуємо на заняттях із СУЛМ. 
Аналіз останніх досліджень і публікацій. Проектні технології залучили до навчальної практики ще у 20-ті роки минулого століття в США завдяки дослідженням американського філософа, педагога й психолога Дж. Дьюї, якого вважають основоположником цієї технології. Він стверджував, що здібності притаманні дитині від народження, а школа має створити умови для їх розкриття, тому й запропонував будувати навчальний процес на активній основі на підставі діяльності учнів 3 урахуванням їхньої особистої зацікавленості в конкретних знаннях.

Ідеї Дж. Дьюї студіювали В. Кілпатрик та Ф. Паркер, які намагалися організувати активну пізнавальну діяльність учнів на основі їхнього спільного пошуку під час роботи над проектом. Водночас різні види діяльності, до яких залучали учнів, сприяли не лише розширенню світогляду, життєвого досвіду, а й забезпечували оволодіння різними способами творчої й дослідницької діяльностей. У проектному навчанні застосовували активні методи, колективні форми роботи. Запропоновану технологію й дотепер активно використовують у практиці американської школи. Е. Кагаров, проаналізувавши досвід застосування проектної діяльності В. Чартерса, Стівенсона, В. Кілпатрика, Вудхелла, Р. Уоткінса, зазначив, що, незважаючи на відмінність позицій щодо сутності методу проектів, американські педагоги акцентують на тих самих концептуальних рисах:

- принцип активності у виборі завдання та його виконанні;

- життєвий, практичний характер проектів, суспільно-корисну цільову установку;

- інтерес до роботи;

- поєднання теорії й практики, знань і навичок;

- здатність проекту породжувати в процесі роботи нові ідеї [2].

Згодом проектні технології набули популярності у Великій Британії, Бельгії, Німеччині, Італії, Фінляндії та інших країнах. На межі 1910-1920-х рр. метод проектів залучають і до практики вітчизняної школи (С. Шацький, В. Шульгіна, М. Крупеніна).

Теоретичні аспекти проектних технологій стали об'єктом досліджень таких науковців та педагогів, як П. Архангельський, В. Безрукова, В. Беспалько, Л. Ващенко, Л. Закота, О. Зосименко, Г. Ісаєва, В. Краєвський, І. Лернер, С. Москвін, Л. Переверзєв, О. Пєхота, Є. Полат, О. Пометун, Л. Ричкова, В. Сипченко, С. Сисоєва, С. Стефансон, А. Хуторський, К. Яресько та інші.

Грунтовним виданням $є$ науково-методичний збірник Центру проблем розвитку освіти Білоруського державного університету, що містить матеріали та рекомендації для організації й використання методу проектів у навчальному процесі сучасних вишів. До збірника увійшли дослідження Є. Полат «Метод проектів», у якому автор основну увагу зосереджує на телекомунікаційному проекті [3]; В. Гузєєва «Проектне навчання як одна 3 інтегральних технологій», де подано теорію методу проектів (види проектів, етапи та стадії роботи над проектом), зокрема, проаналізовано технологію «Спрямовуючого проекту», який, на думку науковця, належить до п’ятого покоління освітніх технологій, бо передбачає активне залучення інтернет-технологій, та освітню технологію ТОГІМ (Технологія Освіти в Глобальній Інформаційній Мережі) (автор В. Гузеєв), яка реалізує діяльнісно-ціннісний підхід до освіти [4].

На сьогодні проекти ефективно й часто застосовують у навчально-виховному процесі як середньої, так і вищої школи під час вивчення будь-якого предмета чи курсу. Останнім часом з'явилася низка публікацій щодо специфіки використання методу проектів із географії [5], іноземної мови [6], української мови та літератури [7], зарубіжної літератури [8] тощо. 
Мета статті - проаналізувати особливості й алгоритм реалізації методу проектів під час вивчення курсу «Сучасна українська літературна мова» студентами філологічного факультету, використовуючи інформаційно-технічні засоби.

\section{2. МЕТОДИКА ДОСЛІДЖЕННЯ}

Для реалізації окресленої мети використано низку основних методів дослідження, a саме: загальні методи дослідження, зокрема аналіз науково-методичної та наукової літератури щодо реалізації методу проектів у навчальному процесі під час вивчення сучасної української літературної мови, синтез авторських напрацювань, узагальнення набутих навичок. Методика дослідження передбачає врахування продуктивних можливостей методів проектів для визначення особливостей удосконаленої, перспективної технології вивчення сучасної української літературної мови, аналіз, їх використання під час практичних занять; у роботі використано метод педагогічного спостереження за результатами педагогічної діяльності студентів та систематизацію й узагальнення власного досвіду впровадження проектних технологій у вивчення курсу «Сучасна українська літературна мова».

\section{3. РЕЗУЛЬТАТИ ДОСЛІДЖЕННЯ}

Згідно з програмою навчальної дисципліни «Сучасна українська літературна мова» переважна кількість годин на засвоєння студентами філологічного факультету ДВНЗ «Донбаський державний педагогічний університет» курсу граматики української мови - це самостійна робота, яка спонукає до розв'язання пізнавальних завдань, формує певну систему інтелектуальних i практичних умінь, сприяє самовдосконаленню, саморозвитку, самореалізації.

Для кращого самостійного опрацювання і засвоєння теоретичного матеріалу використовуємо як традиційні, так й інноваційні форми самостійної роботи, зокрема технологію проектів, яка підвищує ефективність застосування теоретичних знань на практиці, урізноманітнює форми роботи зі студентами на практичних заняттях, сприяє продуктивності самостійного опрацювання матеріалу.

Використання методу проектів на заняттях із СУЛМ підвищує ефективність формування у студентів мовних і мовленнєвих компетентностей завдяки вербальним i невербальним засобам засвоєння навчального матеріалу, оптимізує освітній процес i підвищує його якість. Проектні технології допомагають не лише урізноманітнювати виклад інформації на занятті, а й зробити його цікавим, оригінальним.

Метод проектів передбачає розв'язання певної проблеми, трансльованої 3 реального життя, а це означає - використання різних засобів (прийомів, форм) навчання та поєднання знань 3 науково-технічних i творчих галузей. Робота над проектом - практика особистісно орієнтованого навчання в процесі конкретної праці студента, на підставі його вільного вибору, з урахуванням його інтересів. У свідомості студента це має такий вигляд: «Усе, що я пізнаю, я знаю, для чого це мені треба і де я можу ці знання застосувати» [9, с. 149]. Для викладача, який традиційно $\epsilon$ комунікатором, - це прагнення віднайти оптимальний баланс між академічними й прагматичними знаннями, уміннями та навичками.

Під методом проектів розуміємо «спосіб досягнення дидактичної мети через детальну розробку проблеми (технологію), що має завершитися реальним, відчутним практичним результатом, оформленим тим чи тим способом» [3, с. 41]. 
Проектна технологія має «стимулювати інтерес учнів до певних проблем, що передбачають володіння визначеною сумою знань, та через проектну діяльність, яка передбачає розв'язання однієї або цілої низки проблем, показати практичне застосування набутих знань» [9, с. 150].

За визначенням С. Сисоєвої, метод проектів є однією з педагогічних технологій, «яка відображає реалізацію особистісно орієнтованого підходу в освіті (саме педагогічною технологією, хоча у назві технології використовується слово «метод») і сприяє формуванню уміння адаптуватися до швидкозмінних умов життя людини постіндустріального суспільства» [10, с. 126]. Цю позицію щодо технологічності методу проектів поділяють І. Срмаков [11], Ю. Загуменнов, Л. Шелкович, Г. Шварц [12], Г. Столяренко, О. Дем'яненко [13], Г. Ісаєва [14], О. Задерей [15], І. Зозюк [16], І. Гусь, І. Калмикова [17] та ін.

«Український педагогічний словник» подає таке визначення методу проектів: організація навчання, «за якою учні набувають знань і навичок у процесі планування й виконання практичних завдань-проектів» [18, с. 205]. Але будь-яке визначення буде неповним з огляду на сутнісні ознаки методу проектів, тому О. Задерей [15], узявши до уваги визначення науковців і педагогів-практиків, уклала таку номенклатуру сутнісних ознак методу проектів:

- самостійна діяльність студентів (індивідуальна, парна чи групова), яку вони виконують упродовж визначеного проміжку часу;

- розв'язання проблеми, яка передбачає використання різноманітних методів, засобів навчання, інтегрування знань, умінь з різних галузей науки, техніки, творчості;

- «відчутність» результатів виконання проекту (якщо це теоретична проблема, то конкретне її розв'язання, якщо практична - конкретний результат, готовий до впровадження);

- використання педагогом сукупності дослідницьких, пошукових, творчих за своєю сутністю методів, прийомів, засобів [9, с. 150];

- не пасивне, а активне сприйняття «навчання через дію»;

- зміщення акцентів у діяльності з формального запам'ятовування на активне мислення;

- застосування «принципів» (загальнодидактичних або частковометодичних) лише за необхідності (ідеться про їх доцільність у конкретних ситуаціях проектування) [19, с. 477];

- планування доцільної (цілеспрямованої) діяльності у зв'язку з вирішенням якого-небудь навчального шкільного завдання в реальних життєвих обставинах [20, с. 353];

- проблематичний акт, приведений у виконання до кінця в його природній установці [21, с. 403];

- творча діяльність, проблемна за формою представлення матеріалу, практична за формою його застосування, інтелектуально насичена за змістом, яка відбувається в умовах постійного конкурсу думок (І. Зимня);

- орієнтування учня на актуалізацію наявних знань і набуття нових для активного включення в проектувальну діяльність у соціокультурному середовищі [22, с. 1];

- розвиток пізнавальних, творчих навичок і вмінь, що потребують самостійного конструювання знань й орієнтації в інформаційному просторі;

- практика особистісно орієнтованого навчання, що враховує в процесі навчання конкретного учня, його вільний вибір та особисті інтереси [13, с. 3]; 
- не інтеграція фактичних знань, а застосування знань і набуття нових, часом через самоосвіту [12, с. 16];

- не лише набуття учнями нових знань, а й освоєння способів діяльності;

- обов'язкова презентація отриманих результатів [23].

У процесі застосування методу проектів викладач має орієнтуватися на вимоги, що висуваються до організації цієї технології:

1) наявність дослідницької проблеми, яка потребує інтегрованих знань, дослідницького пошуку до іiі розв'язання;

2) теоретична, практична, пізнавальна значущість передбачуваних результатів;

3) самостійна (індивідуальна, парна, групова) діяльність;

4) структурування змістової частини проекту 3 указуванням поетапних результатів);

5) використання дослідницьких методів (визначення проблеми досліджуваних завдань, що випливають 3 неї, висунення гіпотези іiі розв'язання, обговорення методів дослідження, оформлення кінцевих результатів, аналіз отриманої інформації, підбиття підсумків, коректування, висновки [24, с. 59].

Науковці й педагоги-практики класифікують навчальні проекти за різними ознаками. А саме:

1. За діяльністю, яка домінує в проекті (дослідницький, пошуковий, творчий, рольовий, прикладний, інформаційний, ігровий, практико-орієнтовний).

2. За предметно-змістовою галуззю знань (монопроект, міжпредметний проект).

3. За характером координації проекту (безпосередній (жорсткий, гнучкий), опосередкований (неявний, що імітує учасника проекту)).

4. За характером контактів (внутрішні та міжнародні) [9, с. 153].

5. За тривалістю виконання проекту (короткої дії, середньої тривалості, довготривалий) [9, с. 153].

6. За кількістю учасників (індивідуальний, парний, груповий).

7. За ступенем складності (простий (вирішення нескладної задачі), складний чи комплексний (охоплює два й більше субпроекти або передбачає різні типи й форми творчої діяльності) [25, с. 108].

8. За характером партнерських взаємодій між учасниками проектування (кооперативний, змагальний, конкурсний).

9. За характером цільових установок:

- втілення ідеї або плану;

- отримання естетичної насолоди;

- подолання інтелектуальних перепон;

- здобуття нових знань і досвіду [17, с. 8-9].

10. За професійною спрямованістю (комунікаційний, екологічний, соціальний тощо).

11. За взаємозалежністю 3 іншими проектами (відокремлений, наскрізний, спіралеподібний, аналогічний).

12. За рівнем самостійності виконання:

- виконується разом з викладачем;

- виконується разом з іншими студентами сумісно з викладачем;

- виконується разом з іншими студентами без керівництва викладача;

- виконується переважно самостійно.

13. За часом виконання:

- у навчальний час (поточний, підсумковий);

- у позанавчальний час; 
- частково в навчальний і позанавчальний час.

14. За кінцевим результатом (матеріальний, особистісний).

15. За формою й методами організації (ділова гра, практична робота тощо) $[22$, c. 2$]$.

16. За сутнісними характеристиками:

- створюваний (продуктивний), пов'язаний з трудовою діяльністю;

- споживчий (підготовка екскурсій, інформаційні послуги тощо);

- проект розв'язання проблеми (науково-дослідницький);

- проект-вправа (проект навчання й тренування для оволодіння певними навичками [13, с. 3].

Незалежно від типу, проект має бути чітко алгоритмізований і мати «відчутну» кульмінацію, тобто певним чином оформлені результати.

Єдиного алгоритму виконання проекту на сьогодні немає. Існують різні схеми етапів проектної роботи (Г. Іонова, П. Мудров, С. Сисоєва та ін.). На нашу думку, найбільш чітко ілюструє технологічність методу проектів структура, запропонована авторами навчально-методичного посібника «Освітні технології», а саме:

1. Підготовка (визначення теми й мети проекту).

2. Планування: а) визначення джерел, засобів збору, методів аналізу інформації, засобів представлення результатів; б) встановлення критеріїв оцінки результату й процесу.

3. Збір інформації (спостереження, робота 3 літературою, анкетування, експеримент).

4. Аналіз (аналіз результатів, формулювання висновків).

5. Подання й оцінка результатів (усний, письмовий звіт, оцінка результатів $\mathrm{i}$ процесу дослідження) [9, с. 154-155].

Загалом, як зауважує Ю. Гущин, «структуру та етапи проекту можна визначити як «5П»: проблема - планування (проектування) - пошук рішення - продукт презентація. Шостим «П» можна додати портфоліо - папку, у якій зібрані всі робочі матеріали проекту (чернетки, щоденні плани, звіти тощо)» [26, с. 12].

Оскільки застосування методу проектів вимагає досить великої кількості часу, серйозної, грунтовної підготовки, технологію проектування використовуємо переважно в позааудиторний час.

За результатами досліджень (пропонували на початку навчального курсу невелику анкету для визначення основних функцій освітніх мереж), переважно молодь цікавиться інтернет-мережами 3 розважальною, комунікативною (спілкування 3 однолітками, друзями, рідними) метою, рідше для здобуття певної інформації (переважно, це новини чи інформація за інтересами; навчальну інформацію для підготовки до практичних занять шукає лише $10 \%$ студентів). Тому вирішили скористатися тим, що наші студенти - це представники «медійного покоління» (як зазначалося вище) й запропонувати їм таку форму самостійної роботи, як метод проектів з використанням інтернет-ресурсів.

Для самостійного опрацювання теми «Займенник» під час засвоєння дисципліни «Сучасна українська літературна мова» студентам другого курсу запропонували такий вид проекту:

- за основною діяльністю - змішаний (дослідницький + творчий + інформаційний);

- за предметною галуззю - предметний (предмет - «Сучасна українська літературна мова» (розділ «Граматика»));

- за тривалістю - середньої тривалості;

- за формою проведення - практичне заняття; 
- за кількістю учасників - груповий.

Опис проекту

Проблема: усвідомлення особливостей функціонування займенників у СУЛМ, їхнього статусу, кваліфікації, розрядів та типів відмінювання.

Мета проекту: зацікавити проблемою, сформувати мотивацію до самостійного дослідження; удосконалювати мовленнєві навички, граматичні, стилістичні, а також навички користування інтернет-ресурсами.

Завдання:

- опрацювання якнайбільшої кількості теоретично-методичного матеріалу 3 інтернет-ресурсів;

- розвивання пізнавальних інтересів та творчих здібностей студентів;

- забезпечення єдності теорії та практики;

- застосування для підготовки проектної презентації інтерактивних форм роботи;

- формування вміння реалізувати набуті знання в майбутній педагогічній діяльності.

Очікувані результати:

- формування мовних і мовленнєвих компетентностей студентів;

- формування навчально-організаційних, навчально-інформаційних, інтелектуальних і творчих умінь та навичок;

- створення різних форм презентації опрацьованого матеріалу, що можна в подальшому використати у власній педагогічні діяльності.

Контроль за реалізацією проекту: самоконтроль і взаємоконтроль. Викладач $є$ комунікатором. Він також призначає консультації, переглядає чернетки, дає рекомендації.

Форми презентації проекту:

- презентація за програмою Power Point з пакету MS Office;

- буклет;

- комплексна система завдань;

- тести, створені за допомогою інтернет-сервісу Майстер-тест;

- інтерактивні вправи, створені за допомогою онлайнового сервісу мультимедійних дидактичних вправ LearningApps;

- лепбук.

3мicm:

1. Загальна характеристика займенника як частини мови.

2. Статус займенника за гетерогенною (нетрадиційною) класифікацією частин мови.

3. Розряди займенників.

4. Особливості відмінювання займенників.

5. Функціонування займенників у різних стилях СУЛМ.

Етапи роботи над проектом:

1. Вибір теми, визначення завдань, типу проекту. Традиційно тематику проекту пропонує викладач, проте можна запропонувати це зробити студентам самостійно чи провести спільне обговорення і визначити напрям спрямування дослідницької роботи.

2. Визначення проблеми дослідження. За допомогою різних інтерактивних вправ («Мозковий штурм», «Мікрофон» тощо) студенти пропонують проблеми, які варто розглянути із запропонованої теми на практичному занятті. Викладач теж висуває пропозиції, пропонує ідеї, корегує думки студентів. Його завдання: підвести до самостійного визначення проблеми і продумування видів робіт для їх реалізації. Проте, звичайно, можна скористатися «домашньою заготовкою» і запропонувати іiї студентам. 
3. Об'єднання в групи, обговорювання можливих методів дослідження. Студенти переважно реально оцінюють власні можливості, тому об'єднуються в групи самостійно. Уже в групах вони розподілять ролі, планують роботу, добирають форми презентації дослідження. За потреби викладач допомагає в аналізі, пошуку інформації, виборі форм презентації.

Працюючи над темою «Займенник», студенти об’єдналися в шість груп за формою виконання проектного завдання. Відповідно кожна група визначила для себе проблему, над якою буде працювати й обрала форму виконання завдання:

1 група - опрацювати матеріал щодо проблеми «Загальна характеристика займенника як частини мови» та створити комплексну систему завдань, яку можна буде використати у майбутній педагогічній діяльності.

Для підвищення ефективності роботи пропонуємо такі орієнтовні приклади завдань:

- Учимося творчо працювати з підручником.

- Удосконалюємо вміння відмінювати займенники.

- Поглиблюємо знання щодо займенників різних типів.

- Висловлюємо власне судження.

- Розвиваємо творчі здібності.

Студент має право розширити види робіт, враховуючи зміст опрацьованого матеріалу.

2 група - опрацювати матеріал щодо проблеми «Статус займенника за гетерогенною (нетрадиційною) класифікацією частин мови» та створити презентацію за програмою Power Point з пакету MS Office.

3 група - опрацювати матеріал щодо проблеми «Розряди займенників» та створити лепбук.

Лепбук - «це книга чи папка будь-якої форми та з будь-якої теми, із вкладеними в неї оформленими в оригінальний спосіб різноманітними міні-книжками, віконечками, малюнками, іграми» [27, с. 7]. Лепбук належить до змішаного типу проектів: він забезпечує дослідницьку, пізнавальну, творчу та ігрову активність студентів. Лепбук інформативний, багатофункціональний, сприяє розвитку уяви, творчості, естетичних смаків, має дидактичні властивості, залучає студентів до світу мистецтва.

4 група - опрацювати матеріал щодо проблеми «Особливості відмінювання займенників» та створити комплекс інтерактивних вправ за допомогою онлайнового сервісу мультимедійних дидактичних вправ LearningApps. Пропонуємо скористатися блогом Аман Ірини Семенівни (http://internet-servisi.blogspot.com/p/learning-apps.html), яка в статті «Інтернет-сервіс мультимедійних дидактичних вправ LearningApps» подає теоретичний матеріал, що допоможе студентам користуватися додатком Web 2.0 для підтримки освітніх процесів у навчальних закладах різних типів.

5 група - опрацювати матеріал щодо проблеми «Функціонування займенників у різних стилях СУЛМ» та створити тести за допомогою інтернет-сервісу Майстер-тест. Це безкоштовний сервіс, що дозволяє створювати онлайн-тести, скачати і проходити їх без підключення до Інтернету.

Пропонуємо також студентам опрацювати статтю С. Антоненкова «Сім платформ для створення тестів» (Режим доступу: http://osvita.ua/school/method/technol/45747/), щоб обрати кращу платформу для створення тестів.

6 група - учасники обрали назву «Режисери» - готує презентацію практичного заняття, на якому будуть представлені результати студентських досліджень. Їі завдання:

- зрежисерувати основні етапи заняття;

- підготувати сценарій і реалізувати його; 
- спрогнозувати очікувані результати;

- взяти участь в обговоренні на етапі оцінювання проектної роботи.

Потрібно акцентувати, що студенти працюють у команді. Тому можна повторити правила успішної командної роботи, а саме:

Пам’ятай, що ти - частина команди і без тебе команді буде важко.

Будь активним.

Вчасно та ретельно виконуй доручену справу.

Допомагай іншим у разі потреби.

Не «тягни ковдру на себе», пам'ятай, що від тебе команда передусім чекає якісного виконання обов'язків.

Працюй в атмосфері співпраці та взаємовигідного партнерства.

Поважай позицію кожного.

Пам'ятай: успіх кожного - це успіх усіх!

4. Самостійна робота над проектом. Студенти збирають матеріал 3 інтернетресурсів, опрацьовують його.

5. Підготовка до представлення проекту. Викладач 3'ясовує, які засоби презентації проекту необхідні для практичного заняття. Студенти відповідно оформлюють дібраний матеріал, готують презентації.

6. Захист проекту. Творча група «Режисер» разом із викладачем проводить практичне заняття. На цьому етапі, окрім зазначеної роботи, перед початком презентацій застосовують інтерактивну вправу «Дерево очікувань». Стратегія вправи така. На ватмані намальоване велике дерево. Студенти отримують кольорові квіточки, де мають написати свої очікування від практичного заняття (індивідуальне завдання протягом 5 хвилин). Учасники озвучують очікування та прикріпляють їх на «дерево». Викладач коментує «дерево очікувань» для визначення співвідношення очікувань до окреслених завдань проектної роботи.

7. Колективне обговорення проекту. На цьому етапі аналізують результати дослідницької діяльності всіх учасників проекту, зазначають недоліки й переваги обраної форми представлення опрацьованого матеріалу, підбивають підсумки. Важливою $є$ самооцінка учасників проекту.

На етапі рефлексії повертаються до «дерева», проте, це вже «Дерево результатів». Студентам пропонують на плодах (яблуках) написати, чи справдилися їхні очікування, яких результатів вони досягли, яку нову інформацію засвоїли, як зможуть використати засвоєну інформацію в майбутній педагогічній діяльності.

\section{4. ВИСНОВКИ ТА ПЕРСПЕКТИВИ ПОДАЛЬШИХ ДОСЛІДЖЕНЬ}

Отже, використання методу проектів на заняттях 3 курсу «Сучасна українська літературна мова» стимулює і посилює позитивну мотивацію студентів до навчання; $€$ платформою впровадження інтерактивних методів та прийомів; формує навички орієнтування в інформаційному просторі; враховує інтереси та психологічні особливості кожного з учасників дослідницької роботи; дозволяє вчитися на власному досвіді та досвіді інших; розвиває інтелектуальні, організаційні і творчі здібності; уможливлює усвідомлення студентами практичної значущості виконаного проекту.

Проектна технологія корисна як доповнення до основних традиційних видів робіт. Вона вимагає від викладача професійної грамотності, компетенції в інших галузях науки, вільного володіння технічними засобами навчання, уміння толерантно розв'язувати життєві й навчальні суперечності, здійснювати особистісно-професійний саморозвиток, бути справжнім фахівцем. Усе це сприяє успішному впровадженню проектної технології в навчальний процес. 
У подальших науково-методичних дослідженнях плануємо розглянути інші ефективні педагогічні технології й окреслити доцільність їх упровадження в процес підготовки майбутніх учителів-словесників.

\section{СПИСОК ВИКОРИСТАНИХ ДЖЕРЕЛ}

[1] О. Ісаєва, "Креолізований текст на уроках світової літератури як фактор активізації читацької діяльності." [Електронний ресурс]. Доступно : media.ippo.kubg.edu.ua/wpcontent/uploads/2014/.../isaeva_kreolizovanyj_tekst.doc.

[2] Е. Ф. Кагоров, "Ещё о методе проектов", Метод проектів: традииї, перспективи, життєві результати : практико-зорієнтований збірник. Київ, Україна : Департамент, 2003, с. 412-416.

[3] Е. С. Полат, “Метод проектов", Метод проектов: науч.-метод. сб. Серия "Современные технологии университетского образования”, вып. 2. Минск, Белоруссия : РИВШ ББГУ, 2003. c. 39-47. [Електронний ресурс]. Доступно : http://charko.narod.ru/index32.html.

[4] В. В. Гузеев, "Проектное обучение как одна из интегральных технологий”, Метод проектов : науч.-метод. сб. Серия "Современные технологии университетского образования", вып. 2. Минск, Белоруссия : РИВШ ББГУ, 2003. с. 48-62. [Електронний ресурс]. Доступно : http://charko.narod.ru/index32.html.

[5] Н. В. Иванова, "Возможности и специфика применения проектного метода в начальной школе", Начальная школа, № 2, с. 96-101, 2004.

[6] Л. А. Байдурова, та Т. В. Шапошникова, “Метод проектов при обучении учащихся двум иностранным языкам", Иностранные языки в школе, № 1, с. 5-11, 2002.

[7] В. А. Нищета, Технологія життетворчих проектів на уроках украйнської мови та літератури. Харків, Україна : Основа, 2009.

[8] О. О. Середа, "Метод проектів на уроках зарубіжної літератури”, Зарубіжна література в школі, № 5-6, c. 2-9, 2016.

[9] О. М. Пєхота та ін., Освітні технології : навч.-метод. посіб. Київ, Україна : А.С.К., 2001.

[10] С. Сисоєва, "Особистісно зорієнтовані технології: метод проектів", Підручник для директора, № 9-10, с. 25-31, 2005.

[11] I. Срмаков, “Проектний підхід у школі життєвої компетентності”, Підручник для директора, № 910, c. 32-49, 2005.

[12] Ю. Загуменнов, Л. Шелкович, та Г. Шварц, “Особистісно зорієнтовані технології в освіті”, Підручник для директора. № 9-10, с. 10-24, 2005.

[13] Г. Столяренко, та О.Дем'яненко, “Чи можна застосовувати проектні технології на уроках літератури? ”, Украӥнська мова та література, № 45, с. 3-5, 2005.

[14] Г. Ісаєва, "Метод проектів - ефективна технологія навчання", Підручник для директора, № 9-10, c. 4-10, 2005.

[15] О. А. Задерей, "Метод проектної технології та його застосування на заняттях української мови та літератури". [Електронний ресурс]. Доступно : https://olgazaderey.nethouse.ua/static/doc/0000/0000/0044/44364.gtm7umkh4r.doc.

[16] I. Зозюк, “Творчі проекти: обгрунтування необхідності”, Українська мова та література, № 45, с. 67, 2005.

[17] І. М. Гусь, та І. В. Калмикова, “Метод проектів”, Управління школою, № 5, с. 8-11, 2005.

[18] С. Гончаренко, Український педагогічний словник. Київ, Україна : Либідь, 1997.

[19] Л. Левин, "Новые пути школьной работы (Метод проектов в Америке) ", Метод проектів : традииї, перспективи, життєві результати : практико-зорієнтований збірник. Київ, Україна : Департамент, 2003, с. 431-487.

[20] У. Кильпатрик, “Несколько заключительных вопросов”, Метод проектів : традииї̈, перспективи, життєві результати: практико-зорієнтований збірник. Київ, Україна: Департамент, 2003, c. 353 .

[21] М. М. Рубинштейн, “Метод проектов”, Метод проектів : традииїі, перспективи, життєві результати : практико-зорієнтований збірник. Київ, Україна : Департамент, 2003, с. 397-411.

[22] М. В. Чанова, “Некоторые теоретические аспекты реализации метода проектов", Сибирский учитель, № 6, с. 2, 2002.

[23] М. В. Чанова, "Метод проектов в системе проблемного обучения проектов”, Сибирский учитель, № 1, c. 1, 2003.

[24] Е. С. Полат, Новые педагогические и информационные технологи в системе образования. Москва : Академия, 1999. 
[25] Н. Крылова, "Проектная деятельность школьника и педагога: Диалог с воображаемым оппонентом”, Народное образование, № 7, с. 103-111, 2005.

[26] Ю. В. Гущин, “Интерактивные методы обучения в высшей школе”, Психологический журнал Международного университета природы, общества человека “Дубна" / Dubna Psichological Journal, № 2, c. 1-18, 2012. [Електронний ресурс]. Доступно : http://www.fgosvo.ru/uploadfiles/mnenie\%20\%20expertov/2012n2a1.pdf.

[27] А. О. Пляцок, та В. В. Олійник, Використання технології “лепбук” в роботі з дошкільниками : навч.-метод. посібник. Вінниця, Україна: ММК, 2017. [Електронний ресурс]. Доступно : https://dorobok.edu.vn.ua/article/pdf/2043.

\title{
ПРИМЕНЕНИЕ ИНТЕРНЕТ-ОРИЕНТИРОВАННОЙ ПРОЕКТНОЙ ТЕХНОЛОГИИ ПРИ ОБУЧЕНИИ СОВРЕМЕННОМУ УКРАИНСКОМУ ЛИТЕРАТУРНОМУ ЯЗЫКУ В УЧРЕЖДЕНИЯХ ВЫСШЕГО ОБРАЗОВАНИЯ
}

\author{
Решетняк Елена Александровна \\ кандидат филологических наук, доцент кафедры украинского языка и литературы \\ ДВНЗ «Донбасский государственный педагогический университет», г. Славянск, Украина \\ ORCID ID 0000-0002-8039-3929 \\ reshetnyak.alena@ukr.net
}

\begin{abstract}
Аннотация. В статье рассмотрены особенности внедрения проектной технологии в изучение учебной дисциплины «Современный украинский язык» на филологическом факультете в вузе. Как способ и средство изучения и анализа научно-методической литературы определена сущность основных признаков метода проектов, его виды и этапы, определены методика реализации проектной деятельности при изучении филологических дисциплин. Для реализации проектного исследования рекомендуется использовать информационно-коммуникационные технологии, помогающие оптимизировать учебный процесс, сделать его интересным и творческим. Актуальность работы обусловлена необходимостью внедрения в учебный процесс новых эффективных педагогических технологий, интерактивных методов и приемов обучения, помогают развивать познавательные способности студенчества, формировать умение находить пути решения определенных проблем благодаря привлечению различных форм деятельности.
\end{abstract}

Ключевые слова: речь; компетентность; проектные технологии (метод проекта); самостоятельная работа; инновационные формы работы; интерактивные упражнения; интернет-ресурсы.

\section{THE APPLICATION OF THE INTERNET-ORIENTED PROJECT TECHNOLOGY OF TEACHING OF MODERN UKRAINIAN LITERARY LANGUAGE IN THE UNIVERSITY}

\author{
Olena A. Reshetnyak \\ PhD (Philology), Associate Professor of the Department of Ukrainian Language and Literature \\ Donbass State Pedagogical University, Slavyansk, Ukraine \\ ORCID ID 0000-0002-8039-3929 \\ reshetnyak.alena@ukr.net
}

\begin{abstract}
In the article the author considers the features of implementation of a project technology in studying of a discipline «Modern Ukrainian Language» on Philology Department in high school. The essence of the main features of the project method as a method and means of studying and analyzing scientific and methodological literature, its types and stages are determined, the methodology for implementing the project activity in the study of philological disciplines is also defined. To implement the project research the author recommends to use information and communication technologies that help to optimize the learning process, make it interesting and
\end{abstract}


creative. The topicality of the work is conditioned by the need to implement new effective pedagogical technologies, interactive methods and methods of teaching in the learning process, which help to develop cognitive abilities of students, form the ability to find ways to solve certain problems by attracting various forms of activity.

Keywords: speech; competence; project technologies (project method); individual work; innovative forms of work; interactive exercises; Internet resources.

\section{REFERENCES (TRANSLATED AND TRANSLITERATED)}

[1] O. Isaeva, A criolized text at the lessons of world literature as a factor in activating readership https:// media.ippo.kubg.edu.ua/wp-content/uploads/2014/.../isaeva_kreolizovanyj_tekst.doc (in Ukrainian)

[2] E. F. Kaharov, "More about the method of projects", Project method: traditions, perspectives, life's results: a practice-oriented collection. Kyiv, Ukraine: Departament, 2003, p. 412-416. (in Russian)

[3] E. S. Polat, "Project method", Method of projects: scientific and methodical collection. Series "Modern technologies of university education”, Vol. 2. Minsk, Belorussia: RIVSH BBHU, 2003. p. 39-47. http://charko.narod.ru/index32.html. (in Russian)

[4] V. V. Huzeev, "Project training as one of the integral technologies", Method of projects: scientific and methodical collection. Series "Modern technologies of university education", Vol. 2. Minsk, Belorussia: RIVSH BBHU, 2003. p. 48-62. http://charko.narod.ru/index32.html. (in Russian)

[5] N. V. Ivanova, "Opportunities and specificity of the application of the project method in primary school”, Nachalnaia shkola, № 2, p. 96-101, 2004. (in Russian)

[6] L. A. Bajdurova and T. V. Shaposhnikova, "The project method for teaching students in two foreign languages”, Inostrannye iazyki v shkole, № 1, p. 5-11, 2002. (in Russian)

[7] V. A. Nischeta, The technology of living creativity projects in the lessons of the Ukrainian language and literature. Kharkiv, Ukraine: Osnova, 2009. (in Ukrainian)

[8] O. O. Sereda, "The method of projects in the lessons of foreign literature", Zarubizhna literatura $v$ shkoli, № 5-6, p. 2-9, 2016. (in Ukrainian)

[9] O. M. Pekhota, etc. Educational technologies: educational-methodical manual. Kyiv, Ukraine: A.S.K., 2001. (in Ukrainian)

[10] S. Sysoeva, "Personally oriented technologies: project method”, Pidruchnyk dla dyrektora, № 9-10, p. 25-31, 2005. (in Ukrainian)

[11] I. Ermakov, "Project approach in school of life competence”, Pidruchnyk dla dyrektora, № 9-10, p. 3249, 2005. (in Ukrainian)

[12] Iu. Zahumennov, L. Shelkovych and H. Shvarts, "Personally oriented technologies in education", Pidruchnyk dla dyrektora, № 9-10, p. 10-24, 2005. (in Ukrainian)

[13] H. Stolarenko and O. Demianenko, "Can project technology be used in literature lessons?", Ukrainska mova ta literatura, № 45, p. 3-5, 2005. (in Ukrainian)

[14] H. Isaeva, "The project method as an effective learning technology”, Pidruchnyk dla dyrektora, № 9-10, p. 4-10, 2005. (in Ukrainian)

[15] O. A. Zaderej, The method of project technology and its application in the classes of Ukrainian language and literature. https://olgazaderey.nethouse.ua/static/doc/0000/0000/0044/44364.gtm7umkh4r.doc. (in Ukrainian)

[16] I. Zozuk, "Creative projects: justification of necessity”, Ukrainska mova ta literatura, № 45, p. 6-7, 2005. (in Ukrainian)

[17] I. M. Hus and I. V. Kalmykova, "Method of projects", Upravlinna shkoloiu, № 5, p. 8-11, 2005. (in Ukrainian)

[18] S. Honcharenko, Ukrainian pedagogical dictionary. Kyiv, Ukraine: Lybid, 1997. (in Ukrainian)

[19] L. Levin, "New ways of school work (Project method in America)", Project method: traditions, perspectives, life's results: a practice-oriented collection. Kyiv, Ukraine: Departament, 2003, p. 431-487. (in Russian)

[20] U. Kilpatrik, "A few final questions", Project method: traditions, perspectives, life's results: a practiceoriented collection. Kyiv, Ukraine: Departament, 2003, p. 353. (in Russian)

[21] M. M. Rubinshtein, "Method of projects", Project method: traditions, perspectives, life's results: a practice-oriented collection. Kyiv, Ukraine: Departament, 2003, p. 397-411. (in Russian)

[22] M. V. Chanova, "Some theoretical aspects of implementing the project method", Sibirski uchitel, № 6, p. 2, 2002. (in Russian)

[23] M. V. Chanova, "Method of projects in the system of problematic project training”, Sibirski uchitel, № 1, p. 1, 2003. (in Russian) 
[24] E. S. Polat, New pedagogical and information technologies in the education system. Moscow: Academia, 1999. (in Russian)

[25] N. Krylova, "Project activity of a schoolboy and a teacher: Dialogue with an imaginary opponent", Narodnoe obrazovanie, № 7, p. 103-111, 2005. (in Russian)

[26] Iu. V. Huschin, "Interactive methods of teaching in higher education", Dubna Psichological Journal, № 2, p. 1-18， 2012. http://www.fgosvo.ru/uploadfiles/mnenie\%20\%20expertov/2012n2a1.pdf. (in Russian)

[27] A. O. Platsok and V. V. Olijnyk, Using the technology of "lapbook" in working with preschoolers: a teaching manual. Vinnitsa, Ukraine: MMK, 2017. https://dorobok.edu.vn.ua/article/pdf/2043. (in Ukrainian)

\section{(cc) BY-NC-SA}

This work is licensed under Creative Commons Attribution-NonCommercial-ShareAlike 4.0 International License. 